Chemical Research In Toxicology

September 2015, Volume 28 Issue 9 Pages 1831-1841

http://dx.doi.org/10.1021/acs.chemrestox.5b00269

http://archimer.ifremer.fr/doc/00284/39490/

(c) 2015 American Chemical Society

\title{
Energy and Antioxidant Responses of Pacific Oyster Exposed to Trace Levels of Pesticides
}

\author{
Epelboin Yanouk ${ }^{1,{ }^{*}}$, Quere Claudie ${ }^{1}$, Pernet Fabrice ${ }^{1}$, Pichereau Vianney ${ }^{2}$, Corporeau Charlotte ${ }^{1}$ \\ ${ }^{1}$ UBO, UMR 6539, CNRS, IFREMER,IRD,Lab Sci Environm Marin LEMAR, F-29280 Plouzane, France. \\ ${ }^{2}$ Univ Brest, UMR 6539, UBO,Inst Univ Europeen Mer, CNRS,UBO,IRD, Ifremer,Lab Sci Environm \\ Marin LEMAR, F-29280 Plouzane, France. \\ * Corresponding author: Yanouk Epelboin, Tel: +332982243 76. Fax: + 33298224653 ; \\ email address : yanouk.epelboin@ifremer.fr
}

\begin{abstract}
:
Here, we assess the physiological effects induced by environmental concentrations of pesticides in Pacific oyster Crassostrea gigas. Oysters were exposed for $14 \mathrm{~d}$ to trace levels of metconazole $(0.2$ and $2 \mathrm{mu} \mathrm{g} / \mathrm{L})$, isoproturon $(0.1$ and $1 \mathrm{mu} \mathrm{g} / \mathrm{L})$, or both in a mixture $(0.2$ and $0.1 \mathrm{mu} \mathrm{g} / \mathrm{L}$, respectively). Exposure to trace levels of pesticides had no effect on the filtration rate, growth, and energy reserves of oysters. However, oysters exposed to metconazole and isoproturon showed an overactivation of the sensing-kinase AMP-activated protein kinase alpha (AMPK alpha), a key enzyme involved in energy metabolism and more particularly glycolysis. In the meantime, these exposed oysters showed a decrease in hexokinase and pyruvate kinase activities, whereas 2-DE proteomic revealed that fructose1,6-bisphosphatase (F-1,6-BP), a key enzyme of gluconeogenesis, was upregulated. Activities of antioxidant enzymes were higher in oysters exposed to the highest pesticide concentrations. Both pesticides enhanced the superoxide dismutase activity of oysters. Isoproturon enhanced catalase activity, and metconazole enhanced peroxiredoxin activity. Overall, our results show that environmental concentrations of metconazole or isoproturon induced subtle changes in the energy and antioxidant metabolisms of oysters.
\end{abstract}




\section{Graphical abstract}

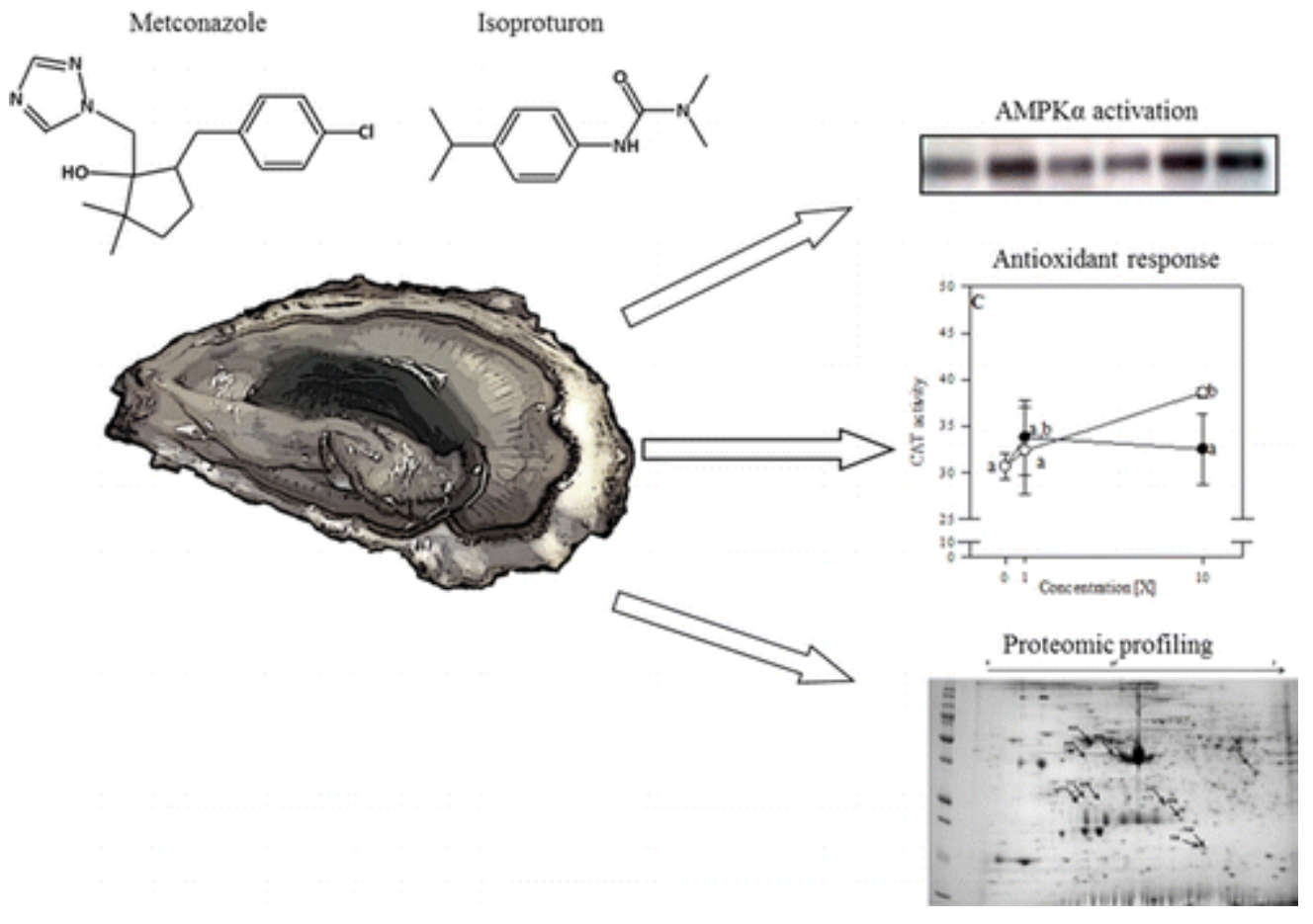




\section{INTRODUCTION}

Coasts and estuaries are often anthropic environments ${ }^{1}$ where pesticides can reach non-target aquatic organisms, such as marine bivalves. ${ }^{2}$ The Pacific oyster Crassostrea gigas is a benthic suspension feeder widely distributed all over the world. Oysters, like other bivalves, bioaccumulate contaminants in their soft tissues, so that they are often used as sentinel animals in the marine environment.

Only few studies have investigated the effect of environmental concentration of pesticides on the physiological responses of oysters. For instance, oysters exposed to trace levels of pesticides, alone or mixed with other contaminants, could exhibit growth reduction, ${ }^{3}$ partial spawning ${ }^{4}$ and developmental anomaly. ${ }^{5,6}$ At the cell level, hemocytes of oysters exposed to pesticides show a reduced phagocytosis which may impair their immune response ${ }^{7,8}$. At the molecule level, oysters exposed to low concentrations of pesticides present differences in gene expression related to energy production, immune system and xenobiotics detoxification..$^{9,10,11}$

The aim of this study is to determine the metabolic response of oysters exposed to trace levels of commonly used pesticides. We analyzed the whole organism (filtration rate, growth and energetic reserves) and molecular responses (targeted and global proteomic) of oysters. This study focused on metconazole and isoproturon, two pesticides that are detected in surface water along the French coasts.

Metconazole is a fungicide that inhibits the biosynthesis of ergosterol, which is an essential component of cell membranes in fungi. This fungicide has been used for nearly 20 years as a growth regulator and protects cereals against foliar diseases. ${ }^{12}$ Isoproturon is an herbicide belonging to the family of substituted urea, which acts as an inhibitor of photosynthesis. It is one of the most extensively used agricultural pesticides in Europe. ${ }^{13}$ 
The novelty of our work is that we particularly investigate the effects of environmentally relevant concentrations of pesticides on 5' AMP-activated protein kinase (AMPK) and its related glycolytic enzymes, hexokinase and pyruvate kinase. This protein kinase has a catalytic activity that is regulated through phosphorylation at Thr 172 and is involved in energy-sensing of the cell. It is very well conserved across the eukaryotic kingdom. ${ }^{14}$ In all species, AMPK $\alpha$ is a Ser/Thr protein kinase that plays a central role in energy homeostasis ${ }^{15}$ by activating ATP-producing catabolic pathways such as lipolysis, glycolysis and glucose uptake and deactivates ATP-consuming anabolic pathways such as glycogen synthesis and lipogenesis by modulation of downstream targets. ${ }^{16}$

Also, we particularly looked at antioxidant defense systems and fatty acid composition as potential indicators of oxidative stress and lipid peroxidation. ${ }^{17}$

\section{EXPERIMENTAL PROCEDURES}

\section{Animals}

Experimental oysters were produced as previously described. ${ }^{18}$ Briefly, forty adults from wild oyster population were transferred to a grow-out farm and then moved on January 8th 2013 to the Ifremer facilities in Argenton (Brittany, France) for conditioning. These animals were held in 500-L flow-through tanks with seawater at $16{ }^{\circ} \mathrm{C}$ enriched with a phytoplankton mixture. Once the oysters were reproductively mature, gametes from 40 individuals $(1 / 3$ males, $2 / 3$ females), obtained by stripping, were mixed. Fertilization and larval rearing were conducted as previously described. ${ }^{18}$ When oysters were $>2 \mathrm{~mm}$ shell length on April 11th 2013, they were transferred to the Ifremer nursery in Bouin (Vendée, France) and then transferred back to Argenton on mid-June 2013. At the beginning of the experiment, around 7000 four monthsold oysters (weight: $0.72 \pm 0.02 \mathrm{~g}$ ) were distributed in 18 tanks ( $287 \mathrm{~g}$ of oysters per tank). Here we intentionally used young oysters to limit the likely confounding effect of reproductive stages and other life history traits such as rearing conditions. The tanks used for the 
experiment were $800 \mathrm{~mL}$ Artemio ${ }^{\circledR}$ Breeding sets $(\mathrm{JBL})$ with an open flow-through seawater system. No mortality was recorded in our experiment.

\section{Experimental design}

Pesticides used in this experiment were purchased from Pestanal® (Sigma-Aldrich). Exposure was done during 14 days under experimental concentrations of metconazole (M) and isoproturon (I). Metconazole was used at $1 \mathrm{X}(0.2 \mu \mathrm{g} / \mathrm{L}, 625 \mu \mathrm{M})$ or $10 \mathrm{X}(2 \mu \mathrm{g} / \mathrm{L}, 6.25 \mathrm{mM})$. Isoproturon was used at $1 \mathrm{X}(0.1 \mu \mathrm{g} / \mathrm{L}, 485 \mu \mathrm{M})$ or $10 \mathrm{X}(1 \mu \mathrm{g} / \mathrm{L}, 4.85 \mathrm{mM})$. In the mixture, metconazole was $1 \mathrm{X}$ and isoproturon $1 \mathrm{X}$. All oysters were fed ad libitum with a daily mixed diet that consisted of Isochrysis affinis galbana (T-ISO) and Chaetoceros gracilis (1:1 in dry weight). Seawater was treated with UV radiation, filtered at $1 \mu \mathrm{m}$, maintained at a temperature of $20 \pm 1{ }^{\circ} \mathrm{C}$ and oxygen saturation of $75 \pm 10 \%$ (5.54 mg/L of seawater). The flow rate of $20 \mathrm{~L} / \mathrm{h}$ took into account the expected concentration of each pesticide in tanks. Three tanks were used for each condition: control oysters in seawater (C), metconazole 1X, metconazole 10X, isoproturon $1 \mathrm{X}$, isoproturon $10 \mathrm{X}$, and the mixture $(\mathrm{M}+\mathrm{I}$ at $1 \mathrm{X})$. Two stock solutions of active substance were prepared at room temperature in ultrapure water: metconazole 62.5 M and isoproturon 48.5 M. Experimental concentrations were obtained by dilution of stock solutions using the sea water flow rate and renewed every 48 hours to ensure a continuous supply of pesticides all along the experiment by a peristaltic pump. Water containing pesticides at the outlet was treated by a $1 \mu \mathrm{m}$ bag filter followed by an active carbon filter. At the end of the experiment, one pool of 16 oysters per tank was sampled in the 3 tanks per condition ( 3 pools per condition). The shell was quickly removed, and flesh was immediately frozen into liquid nitrogen. Pools of flesh were crushed into a fine powder at $196^{\circ} \mathrm{C}$ with a Dangoumeau mill under liquid nitrogen and kept under liquid nitrogen for further analysis.

\section{Detection of pesticides in sea-water}


A 1 L-sample of sea water was collected at the inlet of every 18 tanks at day 1, 7 and 14, then frozen at $-20^{\circ} \mathrm{C}$ until analysis. Detection of metconazole and isoproturon was performed by the Labocéa laboratory (Plouzané, France) as previously described for other pesticides. ${ }^{3}$ The method used for metconazole and isoproturon detection was a solid / liquid extraction (SPE: solid phase extraction) automated and coupled to liquid chromatography with detection by tandem mass spectrometry (MS-MS). The detection limit for metconazole and isoproturon was $0.02 \mu \mathrm{g} / \mathrm{L}$. Assessing the effective concentrations of pesticides in sea water surrounding animals was an important step necessary to validate that exposure to pesticides was done at trace levels concentrations all along the experiment.

\section{Filtration rate and growth}

Feeding supply was expressed in phytoplankton cell biovolume $\left(\mu \mathrm{m}^{3} / \mu \mathrm{L}\right)$, by means of an electronic particles counter (Multisizer 3, Beckman Coulter), and a phytoplankton level of $1500 \mu \mathrm{m}^{3} / \mu \mathrm{L}$ was continuously maintained at the outlet of each tank by modulating the seawater flow. Filtration rate (FR) was determined twice a day and expressed in cell volume per oyster per day $\left(\mu \mathrm{m}^{3} /\right.$ oyster/day $)$ as $F R=[(C i-C o) \times D] / n$, where $\mathrm{Ci}$ is the cell volume at the inlet, Co is the cell volume at the outlet, D is water flow $(\mathrm{L} / \mathrm{h})$ and $\mathrm{n}$ is the number of oysters per tank.

Growth was estimated by the ratio weight of each tank/number of oysters at day 1, 5, 9 and 14 of the experiment.

\section{Carbohydrate content}

Analysis of carbohydrates was performed as previously described, ${ }^{19}$ using $300 \mathrm{mg}$ of flesh powder that was homogenized with a Polytron ${ }^{\circledR}$ PT $2500 \mathrm{E}$ (Kinemetica) at $4{ }^{\circ} \mathrm{C}$ in $3 \mathrm{~mL}$ milliQ water. Samples were then diluted and mixed with a phenol solution $(5 \% \mathrm{~m} / \mathrm{v})$ and 2.5 $\mathrm{mL}$ of $\mathrm{H}_{2} \mathrm{SO}_{4}$ and then incubated for $20 \mathrm{~min}$. Carbohydrates were quantified by a colorimetric 
assay on an Uvikon 941 (Kontron instruments) at 490 and $600 \mathrm{~nm}$. A standard calibration curve was used to calculate total carbohydrates concentration.

\section{Lipid analysis}

Lipids were extracted as previously described, ${ }^{20}$ using $300 \mathrm{mg}$ of flesh powder incubated in 6 $\mathrm{mL}$ dichloromethane/methanol (2:1, v/v). Neutral lipid classes (triacylglycerol and sterols) were analyzed by high performance thin layer chromatography (HPTLC) with a CAMAG system, consisting of a sampler (TLC Sampler 4) and a reader (TLC Scanner 3). The lipids were placed at the top of a silica gel microcolumn $(30 \times 5 \mathrm{~mm}$ internal diameter; Kieselgel; 70-230 mesh [Merck, Lyon, France]; previously heated to $450^{\circ} \mathrm{C}$ and deactivated with $5 \%$ water). Neutral lipids were eluted with $10 \mathrm{~mL}$ of chloroform/methanol $(98: 2, \mathrm{v} / \mathrm{v})$ and polar lipids were eluted with $15 \mathrm{~mL}$ of methanol and lipid fractions were stored at $-20^{\circ} \mathrm{C}$ under nitrogen before further analyses. A known amount of tricosanoic acid was added as internal standard. Lipids were transesterified at $100{ }^{\circ} \mathrm{C}$ for $10 \mathrm{~min}$ with $1 \mathrm{~mL}$ of boron trifluoride $(12 \% \mathrm{Me}-\mathrm{OH})$ and analyzed as previously described. ${ }^{21}$ After cooling and adding $1 \mathrm{~mL}$ of hexane and $1 \mathrm{~mL}$ of milliQ water, the organic phase containing fatty acid (FA) methyl esters was washed with $1 \mathrm{~mL}$ of water. FA methyl ester were analyzed in a HP6890 GC system (Hewlett-Packard). FA methyl esters identification was performed using a DB-Wax capillary column (30 $\mathrm{m} \times 0.25 \mathrm{~mm}$; $0.25 \mu \mathrm{m}$ film thickness; Agilent technologies), by comparison of their retention time with those of a standard 37 component FAME mix and other standards mix from marine bivalves. ${ }^{22}$ FA contents were expressed as the mass percentage of total FA content.

\section{Total protein extraction}

Total protein extraction was performed using $500 \mathrm{mg}$ of flesh powder that was homogenized with a Polytron ${ }^{\circledR}$ PT 2500 E (Kinemetica) at $4^{\circ} \mathrm{C}$ in $5 \mathrm{~mL}$ of lysis $\operatorname{buffer}^{23}(150 \mathrm{mM} \mathrm{NaCl}, 10$ mM Tris pH 7.4, 1 mM EDTA, 1 mM EGTA, 1\% Triton X-100, and 0.5\% Igepal; pH 8.8 at 
$\left.4^{\circ} \mathrm{C}\right)$ containing phosphatase and protease inhibitors $(1 \%$ of Phosphatase inhibitor cocktail II [Sigma-Aldrich], 2\% of NaPPi $250 \mathrm{mM}$, and 1 tablet of complete EDTA free protease inhibitor cocktail [Roche] in $25 \mathrm{~mL}$ of lysis buffer). Solubilized proteins were extracted by centrifugations at $4,000 \mathrm{~g}$ for $1 \mathrm{~h}$ at $4^{\circ} \mathrm{C}$ for elimination of lipids and cellular debris. The phase containing proteins was then collected and centrifuged at $10,000 \mathrm{~g}$ for $45 \mathrm{~min}$ at $4^{\circ} \mathrm{C}$. The resulting lysates were aliquoted and stored at $-80^{\circ} \mathrm{C}$ for further analysis. Total protein content in each lysate was analyzed using the DC protein assay (Bio-Rad), in 96-well microplates (Nunc) using a microplate reader Synergy HT (Bio-Tek). Concentration was obtained using Gen5 version 2.03 software (Bio-Tek).

\section{Hexokinase, pyruvate kinase and citrate synthase activities}

Enzymatic activities of hexokinase (HK; EC 2.7.1.1), pyruvate kinase (PK; EC 2.7.1.40) ${ }^{24}$ and citrate synthase (CS; EC 2.3.3.1) $)^{25}$ were measured using $20 \mu \mathrm{L}$ of total protein lysates. HK assay buffer contains Tris $100 \mathrm{mM}$ pH 8, EDTA $1 \mathrm{mM}, \mathrm{MgCl}_{2} 2 \mathrm{mM}$, glucose $50 \mathrm{mM}$, ATP $10 \mathrm{mM}$, NADP $2 \mathrm{mM}$, glucose-6-phosphate dehydrogenase $10 \mathrm{UI} / \mathrm{mL}$. PK assay buffer contains Imidazole- $\mathrm{HCl} 200 \mathrm{mM}$ pH 7.2, $\mathrm{MgCl}_{2} 5 \mathrm{mM}, \mathrm{KCl} 50 \mathrm{mM}$, phosphoenolpyruvate $100 \mathrm{mM}$, ADP $20 \mathrm{mM}$, lactate dehydrogenase $1.2 \mathrm{UI} / \mathrm{mL}$. For HK and PK, the increase in NADPH or decrease in NADH, respectively, was monitored by measuring absorbance at 340 $\mathrm{nm}$ for $10 \mathrm{~min}$ at $25^{\circ} \mathrm{C}$ using a Synergy ${ }^{\circledR}$ HT microplate reader (BioTek). CS assay buffer contains Tris/HCl $100 \mathrm{mM}$ pH 8, 5,5'-dithio-bis-[2-nitrobenzoic] acid (DNTB) $0.1 \mathrm{mM}$, acetyl-Coenzyme A $0.2 \mathrm{mM}$, oxaloacetate $0.5 \mathrm{mM}$. CS activity is measured by following the increase in TNB absorbance for $10 \mathrm{~min}$ at $412 \mathrm{~nm}$ using a Synergy ${ }^{\circledR}$ HT microplate reader (BioTek). All enzymatic activities were measured and related to the total protein concentration of each sample. 


\section{Superoxide dismutase, catalase, glutathione S-transferase activities}

Total superoxide dismutase (SOD; EC 1.15.1.1) activity was determined using a SOD assay kit (Sigma Aldrich), following manufacturer instruction. SOD activity was measured by adding $200 \mu \mathrm{L}$ of Water Soluble Tetrazolium salt (WST-1) to $20 \mu \mathrm{L}$ of total protein lysates 20 times diluted and reaction was initiated by adding $20 \mu \mathrm{L}$ of xanthine oxidase (XO) and xanthine mix. After incubation at $25{ }^{\circ} \mathrm{C}$ for $20 \mathrm{~min}$, absorbance of samples was read at 450 nm using a Synergy ${ }^{\circledR}$ HT microplate reader (BioTek). A standard inhibition curve was performed using SOD from bovine erythrocytes. SOD activity was expressed in units per mg of protein $(\mathrm{U} / \mathrm{mg}), 1 \mathrm{U}$ of SOD being defined as the amount of enzyme inhibiting by $50 \%$ the xanthine/XO complex formation. Catalase (CAT; EC 1.11 .16$)^{26}$ activity was measured using $8 \mu \mathrm{L}$ of total protein lysates diluted into $792 \mu \mathrm{L}$ of $\mathrm{H}_{2} \mathrm{O}_{2}$ solution. Activity was measured for $1 \mathrm{~min}$ at $240 \mathrm{~nm}$ using a spectrophotometer Uvikon923 (Kontron instruments) by reading the consumption of hydrogen peroxide $10 \mathrm{mM}\left(\mathrm{H}_{2} \mathrm{O}_{2}\right)$. Results were expressed in units per $\mathrm{mg}$ of protein $(\mathrm{U} / \mathrm{mg})$ corresponding to the consumption of $1 \mu \mathrm{mol}$ of $\mathrm{H}_{2} \mathrm{O}_{2}$ per min per mg of protein.

Glutathione S-transferase activity (GST; EC 2.5.1.18) ${ }^{27}$ was measured using $15 \mu \mathrm{L}$ of total protein lysates 10 times diluted. GST buffer assay contains 1-chloro-2,4 dinitrobenzene $1 \mathrm{mM}$ $(\mathrm{CDNB})$ and reduced glutathione $1 \mathrm{mM}(\mathrm{GSH})$ as substrates. After a short incubation of 5 $\min$ at $25^{\circ} \mathrm{C}$, absorbance was read for $3 \mathrm{~min}$ at $340 \mathrm{~nm}$ at $25^{\circ} \mathrm{C}$ using a Synergy ${ }^{\circledR} \mathrm{HT}$ microplate reader (BioTek). Results were expressed in units per mg protein $(\mathrm{U} / \mathrm{mg})$ corresponding to the production of $1 \mu \mathrm{mol}$ of product per minute.

\section{SDS-PAGE and Western Blot}

Total protein lysates were adjusted to $3 \mathrm{mg} / \mathrm{mL}$, mixed with $4 \mathrm{X}$ loading buffer containing $5 \%$ $\beta$-mercaptoethanol and heated for 5 minutes at $95^{\circ} \mathrm{C}$. For mono-dimensional electrophoresis, $40 \mu \mathrm{g}$ of total protein lysate was loaded on $10 \%$ Mini-PROTEAN $^{\circledR}$ TGX $^{\mathrm{TM}}$ precast 
polyacrylamide gel (Biorad). The quantification of AMPK $\alpha \mathrm{Thr}^{172}$ phosphorylation was done by immunodetection in Western-blot, using methods already validated in our model. ${ }^{28}$ After electrophoresis, proteins were transferred onto a polyvinylidenedifluoride membrane with a Trans-Blot ${ }^{\circledR}$ Turbo ${ }^{\mathrm{TM}}$ Transfer Starter System (Biorad). Membranes were washed in PBSTween $1 \%$ (PBS-T), blocked in $5 \% \mathrm{w} / \mathrm{v}$ BSA in PBS-T for $1 \mathrm{~h}$ at $37^{\circ} \mathrm{C}$, then incubated overnight at $4{ }^{\circ} \mathrm{C}$ with the rabbit polyclonal antibody AMPK $\alpha \mathrm{Thr}^{172}$ phosphorylation (\#2535, Cell Signaling Technology; dilution 1:1000). ${ }^{28}$ After washing with PBS-T, membranes were incubated for $1 \mathrm{~h}$ at room temperature with a horseradish peroxidase-conjugated secondary antibody (\#7074, Cell signaling technology; dilution 1:2500). The immune-reactivity was revealed by using an ECL kit (RPN 2232, GE Healthcare). Bands detected in blots were visualized with enhanced chemi-luminescence detection system G:box (Syngene) and quantification was done using Genetools software v. 4.03 (Syngene). The obtained value is expressed in $\mathrm{OD} / \mathrm{mm}^{2}$, and represents band intensity. To control for identical amounts of total protein loaded onto gels, membranes were dehybridized for $1 \mathrm{~h}$ at room temperature in dehybridizing buffer (glycine $100 \mathrm{mM}, \mathrm{NaCl} 100 \mathrm{mM}, \mathrm{pH}$ 3.2) and rehybridized with the rabbit polyclonal antibody histone H3 (\#9715, Cell Signaling Technology; dilution 1:5000).

\section{Two-dimensional electrophoresis (2-DE)}

Total proteins were extracted using $50 \mathrm{mg}$ of flesh powder homogenized with a pestle in a urea/thiourea buffer ${ }^{29}$ containing urea $7 \mathrm{M}$, thiourea $2 \mathrm{M}$, DTT $0.1 \mathrm{M}, 4 \%$ CHAPS, $0.5 \%$ IPG buffer (pH 4-7, GE Healthcare), 1\% of Phosphatase inhibitor cocktail II [Sigma-Aldrich] and $2 \%$ of NaPPi. Samples were sonicated for $15 \mathrm{~s}$ and centrifuged at $15,000 \mathrm{~g}$ at $4{ }^{\circ} \mathrm{C}$ for $30 \mathrm{~min}$. Protein concentrations were determined using a modified Bradford assay ${ }^{30}$ and adjusted to $400 \mu \mathrm{g}$ of proteins in $250 \mu \mathrm{l}$ of rehydration solution (urea $7 \mathrm{M}$, DTT $0.1 \mathrm{M}, 4 \% \mathrm{CHAPS}$, and $0.2 \%$ IPG buffer). Samples were loaded onto an immobilized $\mathrm{pH}$ gradient (IPG) strip (ImmobilineDryStrip pH 4-7NL, $11 \mathrm{~cm}$, GE healthcare). Three technical replicates were 
carried out to ensure 2-DE reproducibility. IPG strips were passively rehydrated overnight with $250 \mu \mathrm{l}$ of protein sample. Isoelectric focusing was conducted in a Protean IEF electrophoresis system (Biorad) with the following protocol: $100 \mathrm{~V}$ for $2 \mathrm{~h} 30 \mathrm{~min}, 300 \mathrm{~V}$ for $1 \mathrm{~h} 30 \mathrm{~min}$, gradient voltage increase to $1000 \mathrm{~V}$ for $1 \mathrm{~h}$, gradient voltage increase to $8000 \mathrm{~V}$ for $6 \mathrm{~h}, 8000 \mathrm{~V}$ for $10 \mathrm{~h}$, and reduced to $500 \mathrm{~V}$. Focused strips were incubated in an equilibration buffer (Tris- $\mathrm{HCl} 50 \mathrm{mM}$ pH 8.8, urea $6 \mathrm{M}, 30 \%$ glycerol, $2 \%$ SDS and $0.002 \%$ Bromophenol Blue) for two 15 min-periods, with $1 \mathrm{~g} / \mathrm{L}$ dithiothreitol replaced with $48.2 \mathrm{~g} / \mathrm{L}$ iodoacetamide. For second dimension electrophoresis, each strip was applied to $8-16 \%$ Tris$\mathrm{HCl}$ Criterion ${ }^{\circledR}$ precast gel (Biorad) and separated at $100 \mathrm{~V}$ for $35 \mathrm{~min}$ and $180 \mathrm{~V}$ for $65 \mathrm{~min}$. Gels were stained with Coomassie Blue (PhastGel, GE Healthcare), unspecific coloration was destained with an aqueous solution containing 30\% methanol and 7\% acetic acid. Colored 2DE gels were scanned with an imaging system G:box (Syngene) for spot detection and relative quantification. Spots intensities were quantified based on normalized spot volumes, using built-in algorithms included in the Progenesis SameSpots software (version 3.3, Nonlinear Dynamics). Automatic detection was performed by the software, but artifact spots were manually checked and removed. Protein spots with statistically significant $(P<0.05)$ fold induction greater than 1.5 were selected for subsequent identification by mass spectrometry.

\section{Mass spectrometry}

These spots were washed with milliQ water, destained in $\mathrm{NH}_{4} \mathrm{HCO}_{3} 100 \mathrm{mM}$ /acetonitrile $(\mathrm{ACN})(1: 1)$, and dehydrated in $100 \% \mathrm{ACN}$. After rehydration in $\mathrm{NH}_{4} \mathrm{HCO}_{3} 100 \mathrm{mM}$ and dehydration in $100 \% \mathrm{ACN}$, excised spots were air-dried and incubated overnight at $37{ }^{\circ} \mathrm{C}$ in a solution of $12.5 \mathrm{ng} / \mu \mathrm{L}$ modified trypsin (Promega) in $\mathrm{NH}_{4} \mathrm{HCO}_{3} 50 \mathrm{mM}$. The resulting tryptic peptides were extracted from the gel spots by several washes in formic acid/ACN/water as previously described. ${ }^{31}$ The tryptic digests were then concentrated by vacuum centrifugation to reach a final volume of $30 \mu \mathrm{L}$. Mobile $\mathrm{A}\left(\mathrm{H}_{2} \mathrm{O} /\right.$ formic acid, 100:0.1) and $\mathrm{B}(\mathrm{ACN} /$ formic 
acid, 100:0.1) phases for HPLC were delivered by the Ultimate 3000 nanoflow LC system (Dionex, LC Packings). $10 \mu \mathrm{L}$ of peptide mixture was loaded on a trapping precolumn (5 mm $\times 300 \mu \mathrm{m}$ i.d., $300 \AA$ A pore size, Pepmap C18, $5 \mu \mathrm{m}$ ) for $3 \mathrm{~min}$ in $2 \%$ buffer B at a flow rate of $25 \mu \mathrm{L} / \mathrm{min}$. This step was followed by reverse-phase separations at a flow rate of 0.250 $\mu \mathrm{L} / \mathrm{min}$ using an analytical column $(15 \mathrm{~cm} \times 300 \mu \mathrm{m}$ i.d., $300 \AA$ pore size, Pepmap C18, 5 $\mu \mathrm{m}$, Dionex, LC Packings). We ran a gradient ranging from $2 \%$ to $35 \%$ of $\mathrm{B}$ for the first 60 $\min , 35 \%$ to $60 \%$ of $\mathrm{B}$ from $\min 60-85$, and $60 \%$ to $90 \%$ of B from min $85-105$. Finally, the column was washed with $90 \%$ of B for 16 min, and with $2 \%$ of B for 19 min prior to loading of the next sample. The peptides were detected by directly eluting them from the HPLC column into the nanoelectrospray ion source of the LTQ-Orbitrap XL (ThermoScientific) mass spectrometer. An ESI voltage of $1.4 \mathrm{kV}$ was applied to the HPLC buffer using the liquid junction provided by the nanoelectrospray ion source and the ion transfer tube temperature was set to $200^{\circ} \mathrm{C}$. The LTQ-Orbitrap XL instrument was operated in its data-dependent mode by automatically switching between full survey scan MS and consecutive MS/MS acquisition. Survey full scan MS spectra (m/z 400-2000) were acquired in the OrbiTrap with a resolution of $r=60000$ at $\mathrm{m} / \mathrm{z} 400$; ion injection times are calculated for each spectrum to allow for accumulation of 106 ions in the OrbiTrap. The 10 most intense peptide ions in each survey scan with intensity above 2000 counts and a charge state $\geq 2$ were sequentially isolated and fragmented in the ion trap by collision induced dissociation. Normalized collision energy was set to $35 \%$ with an activation time of $30 \mathrm{~ms}$. Peaks selected for fragmentation were automatically put on a dynamic exclusion list for $60 \mathrm{~s}$ with a mass tolerance of $\pm 10 \mathrm{ppm}$.

\section{Data processing protocol}

MS data were saved in RAW file format (ThermoScientific) using XCalibur 2.0.7 with tune 2.4. The data analysis was performed with the Proteome Discoverer 1.2 software supported by Mascot (Mascot server v2.2.07; http://www.matrixscience.com) database search engines for 
peptide and protein identification. MS/MS spectra were compared to the Crassostrea gigas Uniprot Reference Proteome database (UP000005408, July 2014, 25978 sequences, 11649621 residues). ${ }^{32}$ Mass tolerance for $\mathrm{MS}$ and $\mathrm{MS} / \mathrm{MS}$ was set at $10 \mathrm{ppm}$ and $0.5 \mathrm{Da}$, respectively. Trypsine was selected as enzyme with one miscleavage allowed. Protein modifications were fixed carbamidomethylation of Cys and variable oxidation of Met. Identified peptides were filtered based on the Mascot score to obtain a false discovery rate of $1 \%$. Only rank 1 peptides were considered. In the case of peptides shared by different proteins, proteins were automatically grouped. The proteins within a group were ranked according to their score and those reported in the protein table correspond to the top score protein.

\section{Statistical analysis}

Two-way ANOVA were performed on all biochemical parameters to investigate the potential effects of a 14 day exposure of metconazole or isoproturon at two concentrations (1X, 10X), and the effect of the mixture at $1 \mathrm{X}$ concentration compared with control oysters. Where overall differences were detected, Least squares mean (LSMean) multiple comparison test was used to determine which means were significantly different. All these analyses were performed by using SAS software 9.1.3 (SAS institute). Homogeneity of variances was checked and all values with $P<0.05$ were considered statistically significant.

\section{RESULTS}

\section{Detection of pesticides}

Metconazole and isoproturon were not detected in control tank (Table 1). There was a deviation between intended and achieved concentrations of both pesticides (Table 1). For example, at day 14 , concentrations of metconazole and isoproturon $1 \mathrm{X}$ were $0.098 \mu \mathrm{g} / \mathrm{L}$ and $0.138 \mu \mathrm{g} / \mathrm{L}$ while we intended $0.200 \mu \mathrm{g} / \mathrm{L}$ and $0.100 \mu \mathrm{g} / \mathrm{L}$ respectively (Table 1). 


\section{Filtration rate, growth and energy reserves}

Growth and filtration rate of oysters exposed to pesticides were similar to that of control animals $(P>0.05)$. On average, filtration rate was $3.35 \pm 0.04 \times 10^{10} \mu \mathrm{m}^{3}$ of cell per animal per day and body mass of oyster increased of $0.82 \pm 0.05 \mathrm{~g}$ during the 14-day experiment. Energy reserves of oysters as measured as carbohydrates, proteins and the ratio triacylglycerol/sterol were similar between oysters exposed to pesticides and control (Table 2).

\section{Enzyme activities}

HK activity was ca. $25 \%$ lower in oysters exposed to pesticides at $1 \mathrm{X}$ for 14 days compared to that of control animals. However, HK activity in oysters exposed to pesticides at $10 \mathrm{X}$ or exposed to the mixture was not significantly different to that of control (Figure 1A, 1B).

PK activity was $34 \%$ to $46 \%$ lower in oysters exposed to pesticides compared to that of control (Figure 1C, 1D).

Mean CS activity was $27.4 \pm 2.7 \mathrm{mU} / \mathrm{mg}$ and was similar between control and exposed oysters, regardless of concentration (data not shown).

SOD activity was similar in oysters exposed to pesticides at $1 \mathrm{X}$ compared to that of control, but was ca. $16 \%$ higher in oysters exposed to pesticides at $10 \mathrm{X}$ (Figure 2A). When metconazole and isoproturon $1 \mathrm{X}$ were mixed, SOD activity was similar to that of control oysters (Figure 2B).

CAT activity was $26 \%$ higher in oysters exposed to isoproturon $10 \mathrm{X}$ than in control (Figure 2C, 2D).

GST activity remained similar between control and exposed oysters, regardless of concentration (Figure 2E, 2F).

\section{AMPKa Thr ${ }^{172}$ phosphorylation}

Western-blot analysis of AMPK phosphorylation is presented in Figure 3A. Overall, phosphorylation of AMPK $\alpha \mathrm{Thr}^{172}$ was $71 \%$ to $132 \%$ higher in oysters exposed to pesticides 
than in control animals (Figure 3B, 3C). There was no significant difference among exposed oysters, regardless of the type and the number of pesticides and their concentrations.

\section{Global proteomic analyses}

2-DE proteomic was performed to identify changes in the proteome of oysters exposed for 14 days to metconazole 10X or isoproturon 10X. Analysis by Progenesis Samespots software detected 405 spots among the different replicates of Coomassie stained gels.

Oysters exposed to metconazole and isoproturon 10X exhibited changes in the expression of 9 and 3 spots compared to control oysters corresponding to 8 and 2 different proteins respectively (Figure 4). The protein contained in each spot was identified using tandem mass spectrometry (Table 3). Oysters exposed to metconazole 10X showed up-regulation of 2 proteins related to energy metabolism (ATP synthase subunit $\beta$ and fructose-1,6bisphosphatase 1), one protein involved in antioxidant response (peroxiredoxin-5) and one transcription factor (Transcription factor BTF3-like). Oysters exposed to metconazole 10X also showed up-regulation of proteins related to cytoskeleton: severin, actin 2 and thymosin, and down-regulation of Rho GDP-dissociation inhibitor 1. Oysters exposed to isoproturon 10X showed up-regulation of one protein involved in the antioxidant response (14-3-3 protein $\zeta$ ) and one protein involved in amino-acid biosynthesis (phosphoserine phosphatase).

\section{Fatty acids analysis}

All fatty acids (FA) of polar lipids analyzed are presented in table S1. Overall, unsaturation index of FA remained unchanged irrespective of treatments (Figure 5A, 5B). Total dimethylacetals (DMA) of oysters exposed to isoproturon $1 \mathrm{X}$ and isoproturon $10 \mathrm{X}$ increased by 9 and $8 \%$ respectively compared to that of control animals. Total DMA of oysters exposed to metconazole (1X and 10X) and to the mixture of pesticides were similar to that of control animals (Figure 5C, 5D). 


\section{DISCUSSION}

\section{Energy metabolism}

In our study, AMPK $\alpha \mathrm{Thr}^{172}$ phosphorylation increased by between 70 and $130 \%$ in oyster exposed to metconazole or isoproturon. Therefore, it is likely that the over-activation of AMPK is a generic response to pesticides. This however needs further testing with other families of pesticides.

Over-activation of AMPK in response to pesticides also suggests that the energy metabolism of oysters is disturbed. Accordingly, energy metabolism of mice was disturbed during exposure to low concentrations of pesticides as reflected by disturbance of the protein kinase $\mathrm{B}(\mathrm{PKB} / \mathrm{Akt}){ }^{33}$ Also, in crayfish Cherax quadricarinatus exposed to glyphosate, glucose metabolism was disturbed with a decrease of PK activity. ${ }^{34}$

Concomitantly with over-activation of AMPK, HK and PK activities were lower in exposed oysters compared to that of control. This result appears somewhat paradoxical. Indeed, AMPK $\alpha$ generally stimulates glucose uptake and glycolysis by up-regulating HK and PK activities. In our study, it is likely that glucose signaling pathway was deregulated due to a constitutive activation of AMPK $\alpha$ after the exposure to trace levels of pesticides. In fact, in many species, short-term AMPK $\alpha$ activation of several minutes stimulates downstream targets such as HK and PK activities, but a longer term activation of several days can modify gene expression. ${ }^{35}$ We can thus hypothesize that over-activation of AMPK $\alpha$ might downregulates mRNA expression of $\mathrm{HK}$ and $\mathrm{PK}$ on the long-term. Alternatively, pesticides may have directly inhibited HK and PK independently from AMPK as reported in human cells. ${ }^{36}$ Regarding oysters exposed to the mixture of pesticides, AMPK $\alpha$ was also over-activated. Although HK activity was lower in oysters exposed to metconazole $1 \mathrm{X}$ or isoproturon $1 \mathrm{X}$ than in control, no changes were observed in oysters exposed to the mixture of both 
pesticides. This could highlight an antagonistic interaction between metconazole and isoproturon, however, this was not observed for PK activity, which is similar when metconazole and isoproturon were applied alone or in mixture.

2-DE proteomics revealed that the fructose-1,6-bisphosphatase (F-1,6-BP) was up-regulated in oysters exposed to metconazole 10X. These results are consistent with the facts that in these animals $\mathrm{HK}$ and PK activities were lowered, reflecting a decrease in glycolysis and an enhancement of gluconeogenesis. For instance, F-1,6-BP converts fructose-1,6-bisphosphate to fructose 6-phosphate in gluconeogenesis. This might reflect that gluconeogenesis was enhanced to compensate for the inhibition of glycolytic enzymes induced by AMPK $\alpha$ overactivation, as previously reported in mice. ${ }^{33}$

Oysters exposed to metconazole 10X showed up-regulation of the ATP synthase subunit $\beta$. This enzyme catalyzes ATP synthesis from ADP by an electrochemical gradient of protons in the inner mitochondrial membrane during oxidative phosphorylation. ${ }^{37}$ Up-regulation of ATP synthase subunit $\beta$ is consistent with an increase in gluconeogenesis.

Although pesticides clearly influenced the energy metabolism of oysters, they have no effect on filtration rate, growth, and energy reserves. In contrast, growth of oysters is inhibited after a 7 days exposure to diuron at $0.4 \mu \mathrm{g} / \mathrm{L} .^{38}$ Discrepancies between studies may reflect differences in experimental conditions. Indeed, in their experiment, the authors used a closed system with intermittent food supply whereas in our experiment, oysters were kept in a flowthrough system with a continuous supply of ad libitum fresh phytoplankton. Although energy reserves of oysters were not impacted by low dose of pesticides, a long term exposure to high concentrations of pesticides can induce depletion in glycogen, protein and lipid contents in several aquatic animals. ${ }^{34,39,40}$ 


\section{Antioxidant response}

Oysters exposed to a $10 \mathrm{X}$ concentration of pesticides showed higher SOD activity than control. This enzyme is involved in management of reactive oxygen species (ROS) and catalyzes the dismutation of the superoxide radical $\left(\mathrm{O}_{2}{ }^{-}\right)$into hydrogen peroxide $\left(\mathrm{H}_{2} \mathrm{O}_{2}\right)$. Level of ROS generally increases in animals exposed to pollutants such as pesticides. ${ }^{41,42} \mathrm{~A}$ $24 \mathrm{~h}$ exposure to trace levels of diuron decreased SOD activity in oyster C. gigas. ${ }^{7}$ Despite this apparently paradoxical result, our results are consistent with those observed in several bivalve species exposed to contaminants. ${ }^{43,44}$

Oysters exposed to isoproturon 10X showed higher CAT activity than controls. This result agrees well with the fact that the increase in SOD activity in these animals should enhance $\mathrm{H}_{2} \mathrm{O}_{2}$. Catalase is the main enzyme involved in $\mathrm{H}_{2} \mathrm{O}_{2}$ detoxification and its activity generally increases with substrate concentration. Similarly, mussels exposed to pesticides or other organic contaminants had higher CAT activity than controls. ${ }^{45,46,47}$

Interestingly, oysters exposed to metconazole 10X used a different antioxidant pathway from those exposed to isoproturon. Indeed, CAT activity of oysters exposed to metconazole $10 \mathrm{X}$ was not enhanced but expression of peroxiredoxin (Prx), another enzyme involved in $\mathrm{H}_{2} \mathrm{O}_{2}$ detoxification, was up-regulated. In support to this result, transcription of Prx gene in shrimp increase when CAT expression was unchanged and reciprocally. ${ }^{48}$

In contrast to increase in SOD, CAT and Prx, activity of glutathione S-transferase (GST), an enzyme involved in cell detoxification system in oysters exposed to pesticides was similar to that of control as observed in oysters exposed to a low-dose pesticide mixture. ${ }^{49}$ However a tissue-specific response was observed in oysters, with an increase in GST activity in digestive gland but not in gills. Similarly, tissue specific response of antioxidant system (SOD, CAT, GST) was observed in bivalve exposed to pesticides. ${ }^{44,49}$ Moreover, although some synergistic effects were observed in C. gigas exposed to a mixture of a herbicide and a fungicide, ${ }^{3}$ the 
mixture of metconazole and isoproturon used in our study did not lead to increased antioxidant enzymes activity.

Oysters exposed to pesticides showed similar unsaturation index of polar lipids compared to that of control, suggesting that lipid peroxidation was limited. ${ }^{17}$ This may reflect that ROS were efficiently managed by the antioxidant system and the lipid bilayer was not altered by trace levels of pesticides. Oysters exposed to the mixture of pesticides showed a lower unsaturated index than that of controls and pesticides alone, which could suggest synergetic effects of the two tested pesticides on this variable.

Total dimethylacetals (DMA) of oysters exposed to isoproturon were higher than that control animals. DMA is a glycerophospholipid class which contains a vinyl ether linkage at the sn-1 position typical of plasmalogens. Cell membrane of bivalves contain high levels of plasmalogens. ${ }^{50}$ In the bivalve Arctica islandica, ${ }^{51}$ plasmalogens were associated with protection against lipid peroxidation. Therefore, the observed increased of plasmalogens in oysters exposed to isoproturon $10 \mathrm{X}$ may be correlated with the activation of antioxidant pathway (SOD, CAT), reflecting an increase of ROS and a potential role to avoid lipid peroxidation.

\section{Modification of some cytoskeletal components}

Three cytoskeleton proteins were up-regulated in oysters exposed to metconazole $10 \mathrm{X}$ (severin, actin 2, thymosin), which confirmed the well-known generic disturbance of cytoskeleton components by marine pollutants, such as heavy metals in Mytilus galloprovincialis ${ }^{52,53}$ or glyphosate in Unio pictorum. ${ }^{54}$ Severin is a protein that blocks F-actin and causes the fragmentation and depolymerization of actin filaments in a $\mathrm{Ca}^{2+}$ dependent way leading to a disturbance in cytoskeletal remodeling. Thymosin belongs to a group of small proteins that also play a role of actin regulators ${ }^{55}$ and can activate the antioxidant enzyme SOD in some species. ${ }^{56}$ 
In conclusion, environmental concentrations of metconazole and isoproturon induced a metabolic response in oysters. Over-activation of the sensing-kinase AMPK $\alpha$ was associated with a decrease in $\mathrm{HK}$ and $\mathrm{PK}$ activities that might reflect a decreased glycolysis. A compensatory response could be an increase in gluconeogenesis, as revealed by 2-DE, which might explain the maintenance of energy reserves in oyster during the 14-day exposure. In addition, activation of antioxidant response was observed for both pesticides but not for the lowest concentrations. 


\section{FUNDING INFORMATION}

This work was supported by Ifremer (project "TRACES" 2012-14) and thanks are given to René Robert, coordinator at the beginning of the project. The project TRACES is co-funded by the Brittany and Pays de la Loire regions as part of Pole Agronomique de l'Ouest PAO. This program associates Ifremer, Laberca, Testapi, CRC North Britanny, CNC, and beekeeping GIE of Pays de la Loire.

\section{ACKNOWLEDGEMENTS}

The authors are grateful to Bruno Petton and Pierrick Le Souchu for their help in developing the experimental design and for critical discussion. The authors thank Dominique Ratiskol, Isabelle Quéau and Christian Mingant of Ifremer involved in oyster conditioning at the Argenton experimental hatchery. We thank Gaël Durand from Labocéa, Plouzané, France, for the detection of pesticides. We thank Mélanie Lagarrigue, Emmanuelle Com and Charles Pineau from the Proteomics Core Facility Protim, Inserm U1085, Rennes, France. We also thank PRIDE and ProteomeXchange for the dissemination of our data. The authors wish to thanks Marine Fuhrmann, Gaëlle Richard and Lizenn Delisle for their help in laboratory experiments. Special thanks are addressed to Ewan Harney for linguistic revision. Yanouk Epelboin was funded by Ifremer and a Region Bretagne doctoral grant. 


\section{SUPPORTING INFORMATION}

The mass spectrometry proteomics data have been deposited to the ProteomeXchange Consortium $^{57}$ via the PRIDE partner repository with the dataset identifier PXD002116, with reviewer access (Username: reviewer68486@ebi.ac.uk, Password: 9ixKJswa, to access the data please visit: http://www.ebi.ac.uk/pride).

Polar lipid fatty acids composition in Pacific oyster Crassostrea gigas exposed to metconazole, or isoproturon, or both, is provided in table $\mathrm{S} 1$.

\section{ABBREVIATIONS LIST}

AMPK: AMP-activated protein kinase, OsHV-1: Ostreid Herpesvirus 1, PK: Pyruvate kinase, HK: Hexokinase, CS: Citrate synthase, SOD: Superoxide dismutase, CAT: Catalase, GST: Glutathione-S-transferase, GSH: Glutathione, F-1,6-BP: Fructose-1,6-bisphosphatase, XO: Xanthine oxidase, DTNB: 5,5'-dithio-bis-[2-nitrobenzoic], CDNB: 1-chloro-2,4 dinitrobenzene, ROS: Reactive oxygen species, FA: fatty acids, SFA: Saturated fatty acids, MUFA: Mono-unsaturated fatty acids, PUFA: Poly-unsaturated fatty acids, NMI: Nonmethylene-interrupted fatty acids, DMA: Dimethylacetals fatty acids, WST-1: Water Soluble Tetrazolium salt, PKB: Protein kinase B 


\section{REFERENCES}

(1) Hapeman, C. J., Dionigi, C. P., Zimba, P. V., and McConnell, L. L. (2002) Agrochemical and Nutrient Impacts on Estuaries and Other Aquatic Systems. J. Agric. Food Chem. 50, 4382-4384.

(2) Tronczynski, J., and Munschy, C. (2005) Analyse de contaminants organiques (herbicides, PCB, $\mathrm{OCP}, \mathrm{HAP}$ ) dans les eaux estuariennes et marines côtières. Ifremer, Plouzané, France.

(3) Stachowski-Haberkorn, S., Quiniou, F., Nedelec, M., Robert, R., Limon, G., and De La Broise, D. (2008) In-situ microcosms, a tool for assessment of pesticide impacts on oyster spat (Crassostrea gigas). Ecotoxicology 17, 235-245.

(4) Buisson, S., Bouchart, V., Guerlet, E., Malas, J. P., and Costil, K. (2008) Level of contamination and impact of pesticides in cupped oyster, Crassostrea gigas, reared in a shellfish production area in Normandy (France). J. Environ. Sci. Health Part B 43, 655-664.

(5) Mai, H., Morin, B., Pardon, P., Gonzalez, P., Budzinski, H., and Cachot, J. (2013) Environmental concentrations of irgarol, diuron and S-metolachlor induce deleterious effects on gametes and embryos of the Pacific oyster, Crassostrea gigas. Mar. Environ. Res. 89, 1-8.

(6) Akcha, F., Spagnol, C., and Rouxel, J. (2012) Genotoxicity of diuron and glyphosate in oyster spermatozoa and embryos. Aquat. Toxicol. Amst. Neth. 106-107, 104-113.

(7) Luna-Acosta, A., Renault, T., Thomas-Guyon, H., Faury, N., Saulnier, D., Budzinski, H., Le Menach, K., Pardon, P., Fruitier-Arnaudin, I., and Bustamante, P. (2012) Detection of early effects of a single herbicide (diuron) and a mix of herbicides and pharmaceuticals (diuron, isoproturon, ibuprofen) on immunological parameters of Pacific oyster (Crassostrea gigas) spat. Chemosphere 87, 1335-1340.

(8) Gagnaire, B., Gay, M., Huvet, A., Daniel, J.-Y., Saulnier, D., and Renault, T. (2007) Combination of a pesticide exposure and a bacterial challenge: In vivo effects on immune response of Pacific oyster, Crassostrea gigas (Thunberg). Aquat. Toxicol. 84, 92-102.

(9) Boutet, I., Tanguy, A., and Moraga, D. (2004) Molecular identification and expression of two nonP450 enzymes, monoamine oxidase $A$ and flavin-containing monooxygenase 2 , involved in phase I of xenobiotic biotransformation in the Pacific oyster, Crassostrea gigas. Biochim. Biophys. Acta 1679, 29-36.

(10) Tanguy, A., Boutet, I., and Moraga, D. (2005) Molecular characterization of the glutamine synthetase gene in the Pacific oyster Crassostrea gigas: expression study in response to xenobiotic exposure and developmental stage. Biochim. Biophys. Acta 1681, 116-125.

(11) Tanguy, A., Boutet, I., Laroche, J., and Moraga, D. (2005) Molecular identification and expression study of differentially regulated genes in the Pacific oyster Crassostrea gigas in response to pesticide exposure. FEBS J. 272, 390-403.

(12) EFSA, E. F. S. A. (2006) Conclusion regarding the peer review of the pesticide risk assessment of the active substance metconazole.

(13) El Sebai, T., Lagacherie, B., Soulas, G., and Martin-Laurent, F. (2007) Spatial variability of isoproturon mineralizing activity within an agricultural field: Geostatistical analysis of simple physicochemical and microbiological soil parameters. Environ. Pollut. 145, 680-690.

(14) Hardie, D. G., Scott, J. W., Pan, D. A., and Hudson, E. R. (2003) Management of cellular energy by the AMP-activated protein kinase system. FEBS Lett. 546, 113-120.

(15) Hardie, D. G., Salt, I. P., Hawley, S. A., and Davies, S. P. (1999) AMP-activated protein kinase: an ultrasensitive system for monitoring cellular energy charge. Biochem. J. 338, 717-722.

(16) Carling, D., Sanders, M. J., and Woods, A. (2008) The regulation of AMP-activated protein kinase by upstream kinases. Int. J. Obes. 200532 Suppl 4, S55-59.

(17) Parrish, C. C. (2013) Lipids in Marine Ecosystems. Int. Sch. Res. Not. 2013, e604045.

(18) Petton, B., Boudry, P., Alunno-Bruscia, M., and Pernet, F. (2015) Factors influencing diseaseinduced mortality of Pacific oysters Crassostrea gigas. Aquacult Env. Interact. 
(19) DuBois, M., Gilles, K. A., Hamilton, J. K., Rebers, P. A., and Smith, F. (1956) Colorimetric Method for Determination of Sugars and Related Substances. Anal. Chem. 28, 350-356.

(20) Fabienne LE Grand, P. S. (2013) Altered membrane lipid composition and functional parameters of circulating cells in cockles (Cerastoderma edule) affected by disseminated neoplasia. Chem. Phys. Lipids.

(21) Marty, Y., Delaunay, F., Moal, J., and Samain, J.-F. (1992) Changes in the fatty acid composition of Pecten maximus (L.) during larval development. J. Exp. Mar. Biol. Ecol. 163, 221-234.

(22) Soudant, P., Marty, Y., Moal, J., and Samain, J. F. (1995) Separation of major polar lipids in Pecten maximus by high-performance liquid chromatography and subsequent determination of their fatty acids using gas chromatography. J. Chromatogr. B Biomed. Appl. 673, 15-26.

(23) Guévélou, E., Huvet, A., Sussarellu, R., Milan, M., Guo, X., Li, L., Zhang, G., Quillien, V., Daniel, J.Y., Quéré, C., Boudry, P., and Corporeau, C. (2013) Regulation of a truncated isoform of AMPactivated protein kinase $\alpha$ (AMPK $\alpha$ ) in response to hypoxia in the muscle of Pacific oyster Crassostrea gigas. J. Comp. Physiol. [B] 183, 597-611.

(24) Greenway, S. C., and Storey, K. B. (1999) The effect of prolonged anoxia on enzyme activities in oysters (Crassostrea virginica) at different seasons. J. Exp. Mar. Biol. Ecol. 242, 259-272.

(25) Childress, J. J., and Somero, G. N. (1979) Depth-related enzymic activities in muscle, brain and heart of deep-living pelagic marine teleosts. Mar. Biol. 52, 273-283.

(26) Aebi, H. (1984) Catalase in vitro. Methods Enzymol. 105, 121-126.

(27) McFarland, V. A., Inouye, L. S., Lutz, C. H., Jarvis, A. S., Clarke, J. U., and McCant, D. D. (1999) Biomarkers of Oxidative Stress and Genotoxicity in Livers of Field-Collected Brown Bullhead, Ameiurus nebulosus. Arch. Environ. Contam. Toxicol. 37, 236-241.

(28) Guévélou, E., Huvet, A., Galindo-Sánchez, C. E., Milan, M., Quillien, V., Daniel, J.-Y., Quéré, C., Boudry, P., and Corporeau, C. (2013) Sex-Specific Regulation of AMP-Activated Protein Kinase (AMPK) in the Pacific Oyster Crassostrea gigas. Biol. Reprod. biolreprod.113.109728.

(29) Kingtong, S., Kellner, K., Bernay, B., Goux, D., Sourdaine, P., and Berthelin, C. H. (2013) Proteomic identification of protein associated to mature spermatozoa in the Pacific oyster Crassostrea gigas. J. Proteomics 82, 81-91.

(30) Ramagli, L. S. (1999) Quantifying protein in 2-D PAGE solubilization buffers. Methods Mol. Biol. Clifton NJ 112, 99-103.

(31) Corporeau, C., Tamayo, D., Pernet, F., Quéré, C., and Madec, S. (2014) Proteomic signatures of the oyster metabolic response to herpesvirus OsHV-1 $\mu$ Var infection. J. Proteomics 109, $176-$ 187.

(32) Zhang, G., Fang, X., Guo, X., Li, L., Luo, R., Xu, F., Yang, P., Zhang, L., Wang, X., Qi, H., Xiong, Z., Que, H., Xie, Y., Holland, P. W. H., Paps, J., Zhu, Y., Wu, F., Chen, Y., Wang, J., Peng, C., Meng, J., Yang, L., Liu, J., Wen, B., Zhang, N., Huang, Z., Zhu, Q., Feng, Y., Mount, A., Hedgecock, D., Xu, Z., Liu, Y., Domazet-Lošo, T., Du, Y., Sun, X., Zhang, S., Liu, B., Cheng, P., Jiang, X., Li, J., Fan, D., Wang, W., Fu, W., Wang, T., Wang, B., Zhang, J., Peng, Z., Li, Y., Li, N., Wang, J., Chen, M., He, Y., Tan, F., Song, X., Zheng, Q., Huang, R., Yang, H., Du, X., Chen, L., Yang, M., Gaffney, P. M., Wang, S., Luo, L., She, Z., Ming, Y., Huang, W., Zhang, S., Huang, B., Zhang, Y., Qu, T., Ni, P., Miao, G., Wang, J., Wang, Q., Steinberg, C. E. W., Wang, H., Li, N., Qian, L., Zhang, G., Li, Y., Yang, H., Liu, X., Wang, J., Yin, Y., and Wang, J. (2012) The oyster genome reveals stress adaptation and complexity of shell formation. Nature 490, 49-54.

(33) Merhi, M., Demur, C., Racaud-Sultan, C., Bertrand, J., Canlet, C., Estrada, F. B. Y., and GametPayrastre, L. (2010) Gender-linked haematopoietic and metabolic disturbances induced by a pesticide mixture administered at low dose to mice. Toxicology 267, 80-90.

(34) Avigliano, L., Fassiano, A. V., Medesani, D. A., Molina, M. C. R. de, and Rodríguez, E. M. (2014) Effects of Glyphosate on Growth Rate, Metabolic Rate and Energy Reserves of Early Juvenile Crayfish, Cherax quadricarinatus M. Bull. Environ. Contam. Toxicol. 92, 631-635. 
(35) Mantovani, J., and Roy, R. (2011) Re-evaluating the general(ized) roles of AMPK in cellular metabolism. FEBS Lett. 585, 967-972.

(36) Marini, C., Salani, B., Massollo, M., Amaro, A., Esposito, A. I., Orengo, A. M., Capitanio, S., Emionite, L., Riondato, M., Bottoni, G., Massara, C., Boccardo, S., Fabbi, M., Campi, C., Ravera, S., Angelini, G., Morbelli, S., Cilli, M., Cordera, R., Truini, M., Maggi, D., Pfeffer, U., and Sambuceti, G. (2013) Direct inhibition of hexokinase activity by metformin at least partially impairs glucose metabolism and tumor growth in experimental breast cancer. Cell Cycle 12, 3490-3499.

(37) Boyer, P. D. (1997) The ATP synthase--a splendid molecular machine. Annu. Rev. Biochem. 66, 717-749.

(38) Barranger, A., Akcha, F., Rouxel, J., Brizard, R., Maurouard, E., Pallud, M., Menard, D., Tapie, N., Budzinski, H., Burgeot, T., and Benabdelmouna, A. (2014) Study of genetic damage in the Japanese oyster induced by an environmentally-relevant exposure to diuron: Evidence of vertical transmission of DNA damage. Aquat. Toxicol. 146, 93-104.

(39) Mosleh, Y. Y., Paris-Palacios, S., Couderchet, M., Biagianti-Risbourg, S., and Vernet, G. (2005) Effects of the herbicide isoproturon on metallothioneins, growth, and antioxidative Defenses in the aquatic worm Tubifex tubifex (Oligochaeta, Tubificidae). Ecotoxicology 14, 559-571.

(40) Ribeiro, S., Sousa, J. P., Nogueira, A. J. A., and Soares, A. (2001) Effect of endosulfan and parathion on energy reserves and physiological parameters of the terrestrial isopod Porcellio dilatatus. Ecotoxicol. Environ. Saf. 49, 131-138.

(41) Valavanidis, A., Vlahogianni, T., Dassenakis, M., and Scoullos, M. (2006) Molecular biomarkers of oxidative stress in aquatic organisms in relation to toxic environmental pollutants. Ecotoxicol. Environ. Saf. 64, 178-189.

(42) Banerjee, B. D., Seth, V., and Ahmed, R. S. (2001) Pesticide-induced oxidative stress: perspectives and trends. Rev. Environ. Health 16, 1-40.

(43) Richardson, B. J., Mak, E., De Luca-Abbott, S. B., Martin, M., McClellan, K., and Lam, P. K. S. (2008) Antioxidant responses to polycyclic aromatic hydrocarbons and organochlorine pesticides in green-lipped mussels (Perna viridis): Do mussels "integrate" biomarker responses? Mar. Pollut. Bull. 57, 503-514.

(44) Sellami, B., Louati, H., Dellali, M., Aissa, P., Mahmoudi, E., Coelho, A. V., and Sheehan, D. (2013) Effects of permethrin exposure on antioxidant enzymes and protein status in Mediterranean clams Ruditapes decussatus. Environ. Sci. Pollut. Res. 21, 4461-4472.

(45) Wenming, R. J., and Di Giulio, R. T. (1988) Microsomal enzyme activities, superoxide production, and antioxidant defenses in ribbed mussels (Geukensia demissa) and wedge clams (Rangia cuneata). Comp. Biochem. Physiol. Part C Comp. Pharmacol. 90, 21-28.

(46) Porte, C., Sole, M., Albaigés, J., and Livingstone, D. R. (1991) Responses of mixed-function oxygenase and antioxidase enzyme system of Mytilus sp. to organic pollution. Comp. Biochem. Physiol. Part C Comp. Pharmacol. 100, 183-186.

(47) Alves, S. R. C., Severino, P. C., Ibbotson, D. P., da Silva, A. Z., Lopes, F. R. A. S., Sáenz, L. A., and Bainy, A. C. D. (2002) Effects of furadan in the brown mussel Perna perna and in the mangrove oyster Crassostrea rhizophorae. Mar. Environ. Res. 54, 241-245.

(48) Wang, D., Li, F., Chi, Y., and Xiang, J. (2012) Potential relationship among three antioxidant enzymes in eliminating hydrogen peroxide in penaeid shrimp. Cell Stress Chaperones 17, 423-433.

(49) Geret, F., Burgeot, T., Haure, J., Gagnaire, B., Renault, T., Communal, P. Y., and Samain, J. F. (2011) Effects of low-dose exposure to pesticide mixture on physiological responses of the pacific oyster, Crassostrea gigas. Environ. Toxicol.

(50) Kraffe, E., Soudant, P., and Marty, Y. (2004) Fatty acids of serine, ethanolamine, and choline plasmalogens in some marine bivalves. Lipids 39, 59-66. 
(51) Munro, D., and Blier, P. U. (2012) The extreme longevity of Arctica islandica is associated with increased peroxidation resistance in mitochondrial membranes. Aging Cell 11, 845-855.

(52) Gomes, T., Chora, S., Pereira, C. G., Cardoso, C., and Bebianno, M. J. (2014) Proteomic response of mussels Mytilus galloprovincialis exposed to CuO NPs and Cu2+: An exploratory biomarker discovery. Aquat. Toxicol. 155, 327-336.

(53) Victor J Nesatyy, M. J.-F. S. (2007) Proteomics for the analysis of environmental stress responses in organisms. Environ. Sci. Amp Technol. 41, 6891-900.

(54) Malécot, M., Guével, B., Pineau, C., Holbech, B. F., Bormans, M., and Wiegand, C. (2013) Specific proteomic response of Unio pictorum mussel to a mixture of glyphosate and microcystin-LR. J. Proteome Res. 12, 5281-5292.

(55) Huff, T., Müller, C. S. G., Otto, A. M., Netzker, R., and Hannappel, E. (2001) $\beta$-Thymosins, small acidic peptides with multiple functions. Int. J. Biochem. Cell Biol. 33, 205-220.

(56) Kumar, S., and Gupta, S. (2011) Thymosin Beta 4 Prevents Oxidative Stress by Targeting Antioxidant and Anti-Apoptotic Genes in Cardiac Fibroblasts. PLOS ONE 6, e26912.

(57) Vizcaíno, J. A., Deutsch, E. W., Wang, R., Csordas, A., Reisinger, F., Ríos, D., Dianes, J. A., Sun, Z., Farrah, T., Bandeira, N., Binz, P.-A., Xenarios, I., Eisenacher, M., Mayer, G., Gatto, L., Campos, A., Chalkley, R. J., Kraus, H.-J., Albar, J. P., Martinez-Bartolomé, S., Apweiler, R., Omenn, G. S., Martens, L., Jones, A. R., and Hermjakob, H. (2014) ProteomeXchange provides globally coordinated proteomics data submission and dissemination. Nat. Biotechnol. 32, 223-226. 


\section{TABLES}

Table 1. Experimental concentrations of metconazole and isoproturon in $\mu \mathrm{g} / \mathrm{L}$ measured in sea water after 1,7 and $14 \mathrm{~d}$ of exposure.

\begin{tabular}{|c|c|c|c|c|c|}
\hline & Control & $\begin{array}{l}\text { Metconazole } \\
\text { 1X }\end{array}$ & $\begin{array}{c}\text { Isoproturon } \\
1 \mathrm{X}\end{array}$ & $\begin{array}{c}\text { Metconazole } \\
10 X\end{array}$ & $\begin{array}{c}\text { Isoproturon } \\
10 \mathrm{X}\end{array}$ \\
\hline Day 1 & $<\mathrm{LD}$ & 0.113 & 0.121 & 1.786 & 1.208 \\
\hline Day 7 & $<\mathrm{LD}$ & 0.048 & 0.110 & ND & 1.355 \\
\hline Day 14 & $<\mathrm{LD}$ & 0.098 & 0.138 & ND & 1.405 \\
\hline
\end{tabular}

$\mathrm{ND}$, no data

LD, limit of detection

Table 2. Energy reserves of oysters exposed to metconazole, isoproturon, or both. Values are expressed as $\mu \mathrm{g} / \mathrm{mg}$ of flesh $\pm \mathrm{SD}$ for carbohydrate and protein contents. The ratio between triacylglycerol and sterol contents is presented. Values are means $\pm \mathrm{SD}$ ( $\mathrm{n}=3$ tanks). Each sample consists in a pool of 16 oysters collected at day 14 .

\begin{tabular}{lllcccc}
\hline & Control & $\begin{array}{c}\text { Metconazole } \\
\mathbf{1 X}\end{array}$ & $\begin{array}{c}\text { Isoproturon } \\
\mathbf{1 X}\end{array}$ & $\begin{array}{c}\text { Metconazole } \\
\mathbf{1 0 X}\end{array}$ & $\begin{array}{c}\text { Isoproturon } \\
\mathbf{1 0 X}\end{array}$ & $\begin{array}{c}\text { Metconazole 1X } \\
\text { Isoproturon 1X }\end{array}$ \\
\hline Carbohydrate $(\boldsymbol{\mu g} / \mathbf{m g}$ flesh) & $160.82 \pm 30.58$ & $157.56 \pm 40.00$ & $141.68 \pm 16.35$ & $151.70 \pm 33.26$ & $166.89 \pm 16.17$ & $149.87 \pm 21.42$ \\
Triacylglycerol / Sterol & $9.00 \pm 0.29$ & $9.51 \pm 0.21$ & $9.12 \pm 0.23$ & $9.21 \pm 0.38$ & $9.53 \pm 0.20$ & $8.72 \pm 0.93$ \\
Protein $(\boldsymbol{\mu g} / \mathbf{m g}$ flesh) & $194.27 \pm 44.54$ & $188.49 \pm 16.41$ & $176.02 \pm 7.71$ & $162.04 \pm 7.44$ & $166.78 \pm 13.07$ & $182.83 \pm 23.28$ \\
\hline
\end{tabular}


Table 3. Identification of proteins by mass spectrometry.

\begin{tabular}{|c|c|c|c|c|c|c|c|c|c|}
\hline Spot & $\begin{array}{c}\text { Uniprot } \\
\text { accession }\end{array}$ & $\begin{array}{c}\text { NCBI } \\
\text { accession }\end{array}$ & Protein name & $\begin{array}{c}\mathbf{p I} / \mathrm{Mr}(\mathrm{kDa}) \\
\text { theoretical }\end{array}$ & $\begin{array}{l}\mathrm{pI} / \mathrm{Mr}(\mathrm{kDa}) \\
\text { experimental }\end{array}$ & Anova (p) & $\begin{array}{c}\text { Average } \\
\text { fold change }\end{array}$ & $\begin{array}{l}\text { Unique } \\
\text { peptide } \\
\text { matched }\end{array}$ & $\begin{array}{c}\text { Mascot } \\
\text { Score }\end{array}$ \\
\hline
\end{tabular}

Up-regulated by metconazole 10X

\begin{tabular}{|c|c|c|c|c|c|c|c|c|}
\hline 432 & K1RWW5 & CGI_10013347|ATP synthase subunit $\beta$ & $44.9 / 5.1$ & $48 / 5.1$ & $6.960 \mathrm{e}-004$ & 1.5 & 27 & 13274.88 \\
\hline 449 & K1PE57 & CGI_10002689|Severin & $37.2 / 4.88$ & $40 / 5$ & 0.006 & 2.0 & 5 & 182.64 \\
\hline 484 & Q8TA69 & CGI_10018876 Actin 2 & $41.7 / 5.48$ & $38 / 5.4$ & 0.004 & 2.2 & 13 & 958.83 \\
\hline 490 & Q8TA69 & CGI_10018876|Actin 2 & $41.7 / 5.48$ & $38 / 5.3$ & 0.009 & 1.7 & 27 & 11920.34 \\
\hline 510 & K1QSB0 & CGI_10006343 $\mid \begin{array}{l}\text { Fructose-1.6- } \\
\text { bisphosphatase } 1\end{array}$ & $36.8 / 6.70$ & $35 / 6.6$ & 0.050 & 1.7 & 9 & 400.54 \\
\hline 668 & K1QM61 & CGI_10009700|Thymosin & $40.4 / 5.78$ & $22 / 5.9$ & 0.007 & 3.2 & 1 & 36.96 \\
\hline 708 & K1R3T3 & $\mid$ CGI_10019268| $\mid \begin{array}{l}\text { Transcription factor BTF3- } \\
\text { like protein } 4\end{array}$ & $18.4 / 6.58$ & $16 / 6.1$ & 0.030 & 1.5 & 5 & 56.11 \\
\hline 709 & K1R7F8 & CGI_10027917|Peroxiredoxin-5 & $16.6 / 5.99$ & $16 / 6.1$ & 0.010 & 1.6 & 7 & 525.46 \\
\hline
\end{tabular}

Down-regulated by metconazole 10X

\begin{tabular}{l|l|l|l|l|l|l|l|l}
\hline 636 & K1QCM0 & CGI_10019175 & $\begin{array}{l}\text { Rho GDP-dissociation } \\
\text { inhibitor 1 }\end{array}$ & $23.6 / 5.26$ & $25 / 5.1$ & 0.044 & 2.2 \\
\hline
\end{tabular}

Up-regulated by isoproturon $10 \mathrm{X}$

\begin{tabular}{l|l|l|c|l|l|l|l|l|l}
\hline 543 & K1P9N7 & CGI_10014966 $14-3-3$ protein $\zeta$ & $35.1 / 4.91$ & $26 / 4.9$ & 0.010 & 1.6 & 2 & 20.60 \\
559 & K1P9N7 & CGI_10014966|14-3-3 protein $\zeta$ & $35.1 / 4.91$ & $25 / 4.9$ & 0.053 & 1.5 & 2 & 23.11 \\
547 & K1Q596 & CGI_10006178|Phosphoserine phosphatase & $26 / 5.74$ & $25 / 5.8$ & 0.047 & 1.5 & 1 & 29.03
\end{tabular}




\section{FIGURE LEGENDS}

Figure 1. Activity of $\mathrm{HK}$ and $\mathrm{PK}$ in Pacific oyster Crassostrea gigas expressed as $\mathrm{mU} / \mathrm{mg}$ of protein. (A,C) Oysters were exposed to metconazole (black dot) or isoproturon (white dot). 0: no pesticides in control; 1: concentration $1 \mathrm{X}$; 10: concentration $10 \mathrm{X}(\mathrm{B}, \mathrm{D}) \mathrm{C}$ : control oysters; $\mathrm{M}+\mathrm{I}$ : mixture of metconazole $1 \mathrm{X}$ and isoproturon $1 \mathrm{X}$. Letters indicate significant differences (n.s: no significant). Values are means $\pm \mathrm{SD}$ ( $\mathrm{n}=3$ tanks). Each sample consists in a pool of 16 oysters collected at day 14 .

Figure 2. Activity of SOD, CAT and GST in Pacific oyster Crassostrea gigas expressed as $\mathrm{mU} / \mathrm{mg}$ of protein. (A,C,E) Oysters were exposed to metconazole (black dot) or isoproturon (white dot). 0 : no pesticides in control; 1: concentration $1 \mathrm{X} ; 10$ : concentration $10 \mathrm{X}$. (B,D,F) $\mathrm{C}$ : control oysters; $\mathrm{M}+\mathrm{I}$ : mixture of metconazole $1 \mathrm{X}$ and isoproturon $1 \mathrm{X}$. Letters indicate significant differences (n.s: no significant). Values are means \pm SD ( $n=3$ tanks). Each sample consists in a pool of 16 oysters collected at day 14 .

Figure 3. AMPK $\alpha \mathrm{Thr}^{172}$ phosphorylation and Histone $\mathrm{H} 3$ content in Pacific oyster Crassostrea gigas. (A) C: control oysters; M 1X: metconazole 1X; I 1X: isoproturon 1X; M 10X: metconazole $10 \mathrm{X}$; I 10X: isoproturon 10X; $\mathrm{M}+\mathrm{I}$ : mixture of metconazole $1 \mathrm{X}$ and isoproturon 1X. Representative image of western blot of AMPK $\alpha \mathrm{Thr}^{172}$ phosphorylation $(62 \mathrm{kDa})$ and Histone $\mathrm{H} 3$ (10kDa). (B,C) Relative quantification of bands intensity corresponding to AMPK $\alpha \mathrm{Thr}^{172}$ phosphorylation (expressed as \% of the control). (B) Oysters were exposed to metconazole (black dot) or isoproturon (white dot). 0: no pesticides in control; 1: concentration 1X; 10: concentration 10X. (C) C: control oysters; M+I: mixture of metconazole $1 \mathrm{X}$ and isoproturon 1X. Letters indicate significant differences. Values are means $\pm \mathrm{SD}$ ( $\mathrm{n}=3$ tanks). Each sample consists in a pool of 16 oysters collected at day 14 . 
Figure 4. Reference image showing a gel of a 2-DE protein profile of oyster Crassostrea gigas. Excised spots are marked with corresponding spot number: in bold, under metconazole $10 \mathrm{X}$ and in italic, isoproturon 10X. Each sample consists in a pool of 16 oysters collected at day 14. The name of the protein identified is shown in Table 3 and details of the corresponding mass spectrometric data are given in the supplementary data. Mr: molecular marker.

Figure 5. Unsaturated index and total dimethylacetals (DMA, expressed in \% of total FA) content in polar lipids. (A,C) Oysters were exposed to metconazole (black dot) or isoproturon (white dot). 0: no pesticides in control; 1: concentration 1X; 10: concentration 10X. (B,D) C: control oysters; $\mathrm{M}+\mathrm{I}$ : mixture of metconazole $1 \mathrm{X}$ and isoproturon $1 \mathrm{X}$. Letters indicate significant differences (n.s: no significant). Values are means \pm SD ( $n=3$ tanks). Each sample consists in a pool of 16 oysters collected at day 14 . 


\section{FIGURES}

Figure 1
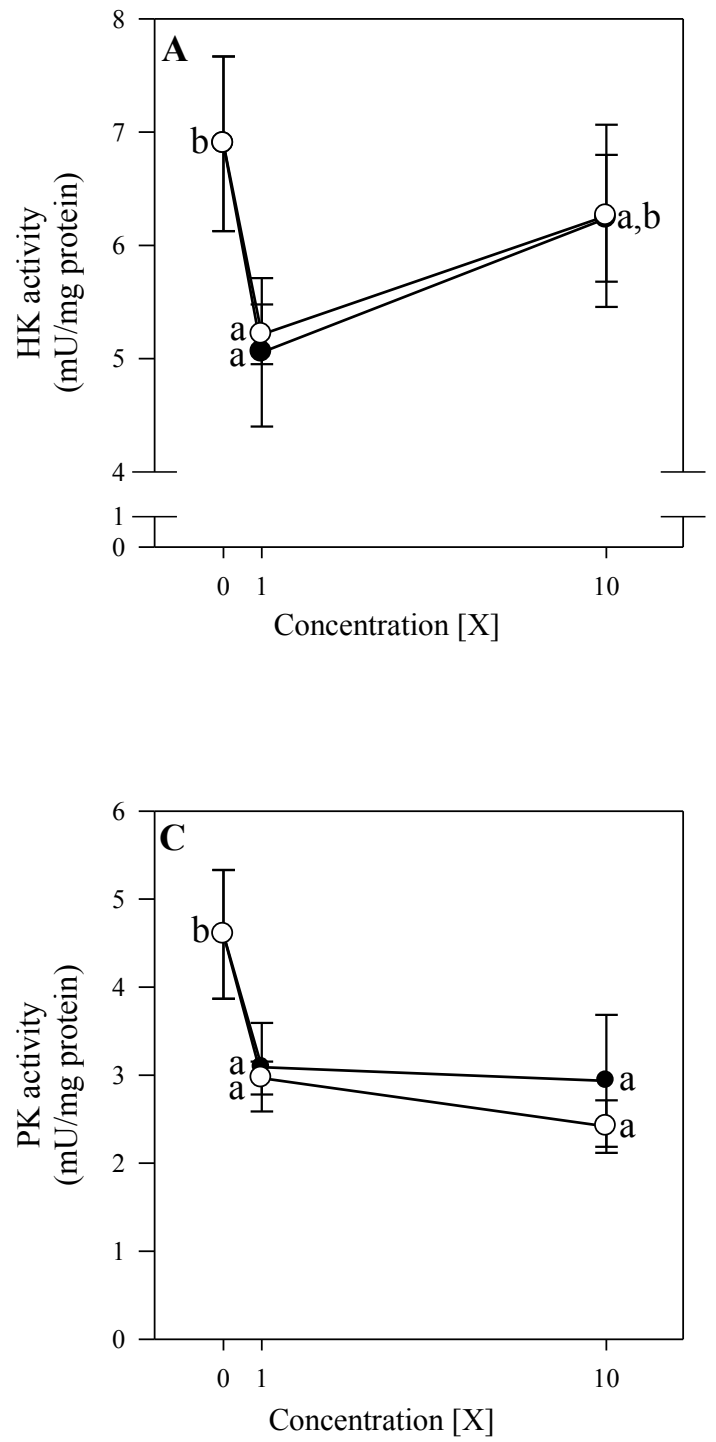
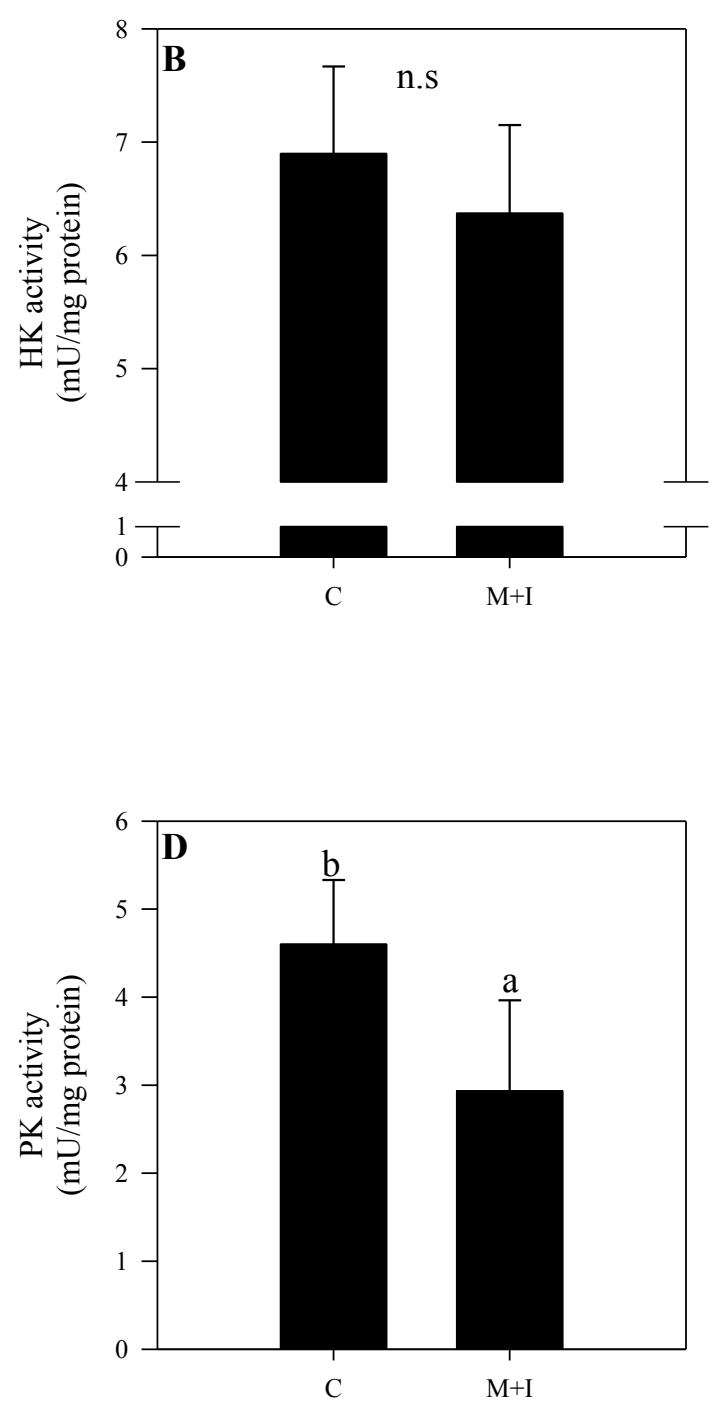
Figure 2
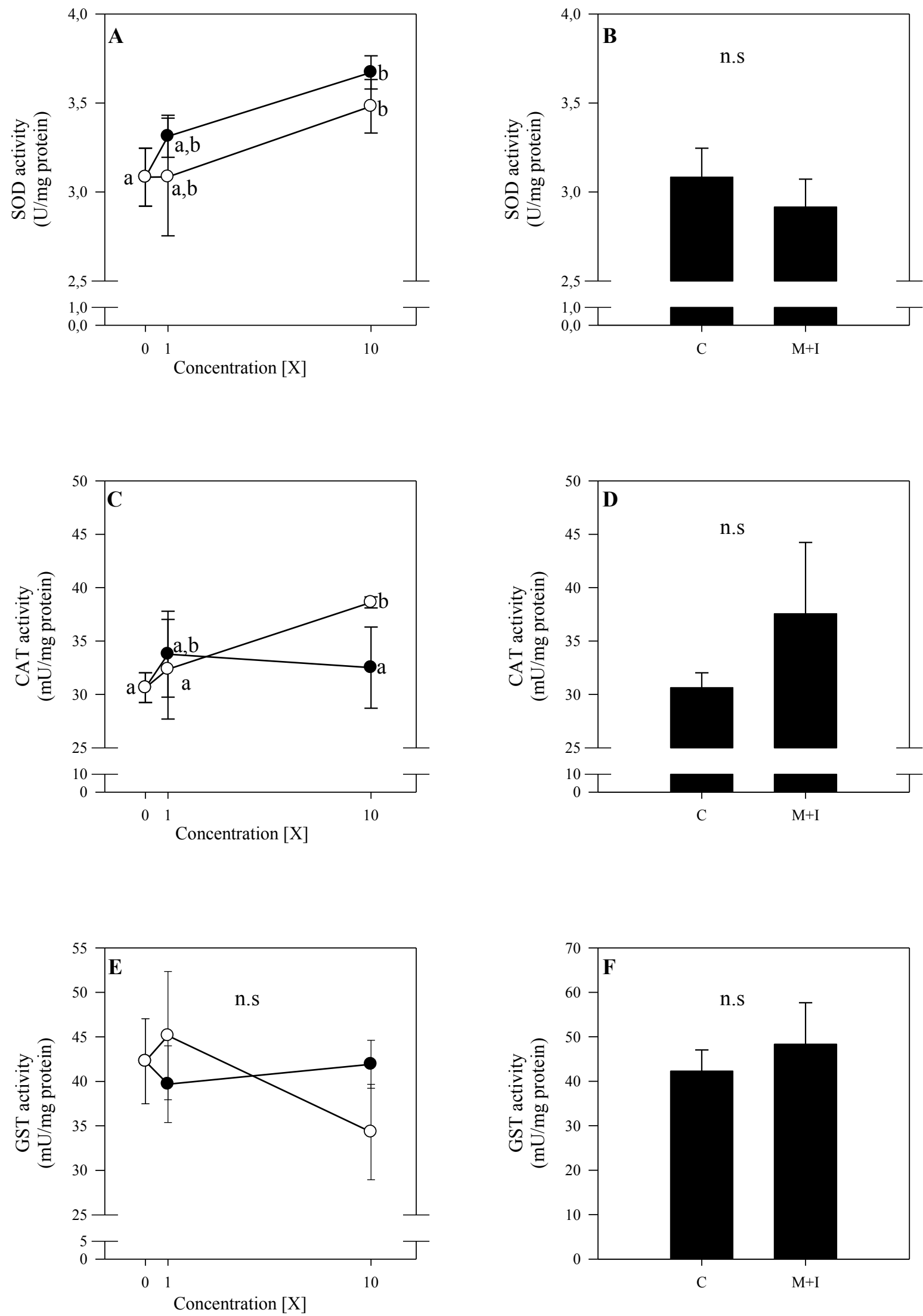
Figure 3
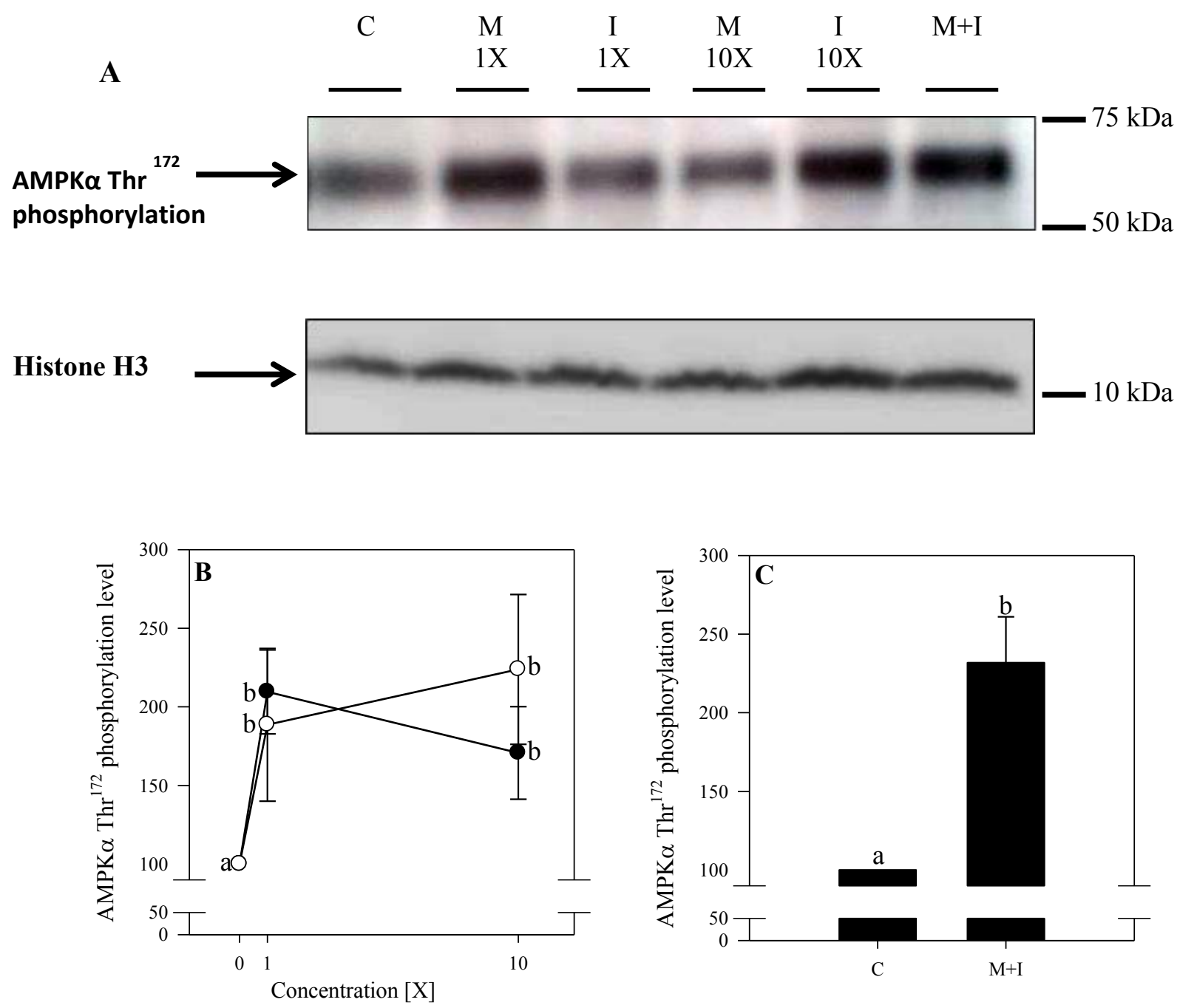
Figure 4.

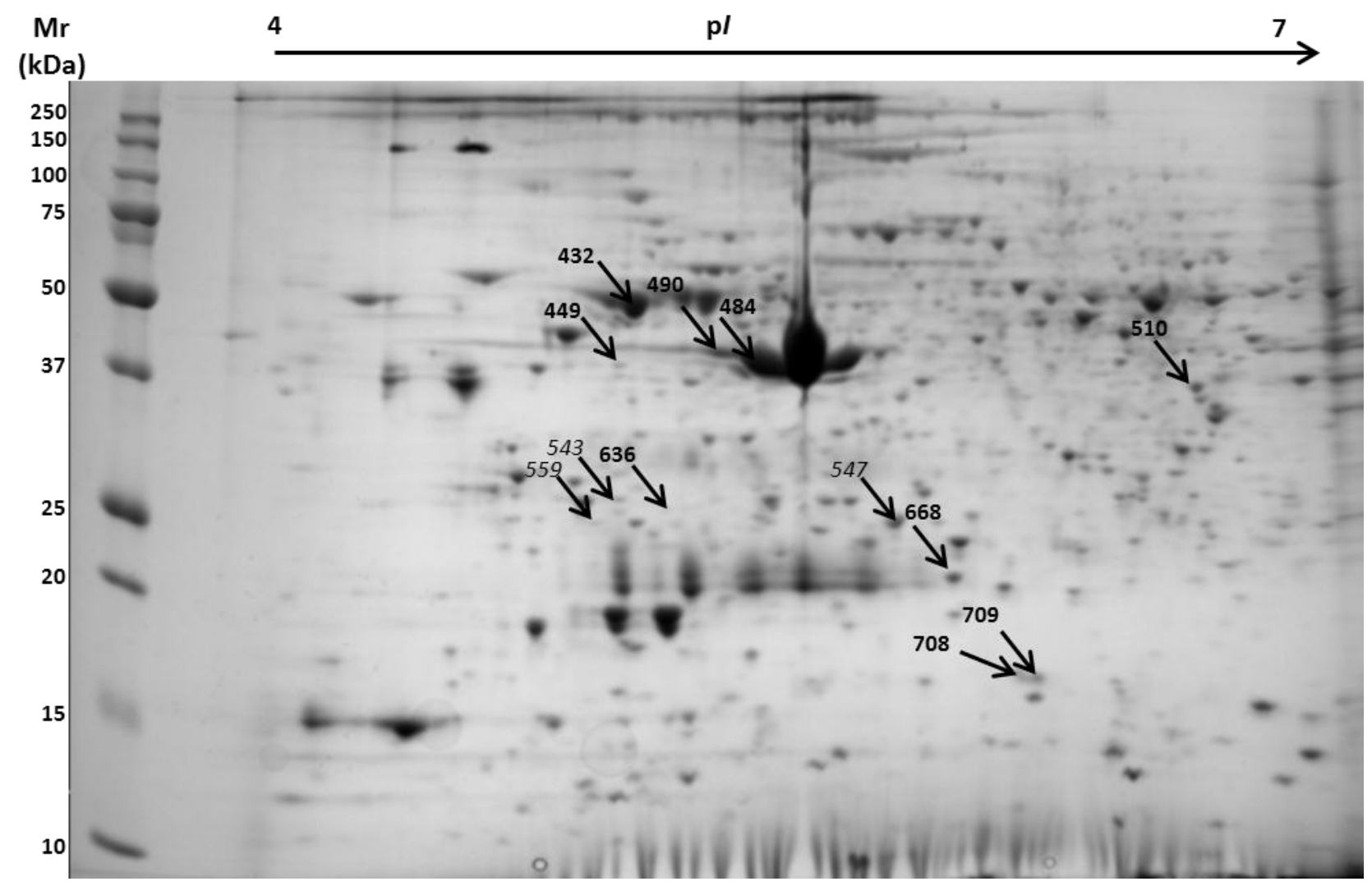


Figure 5
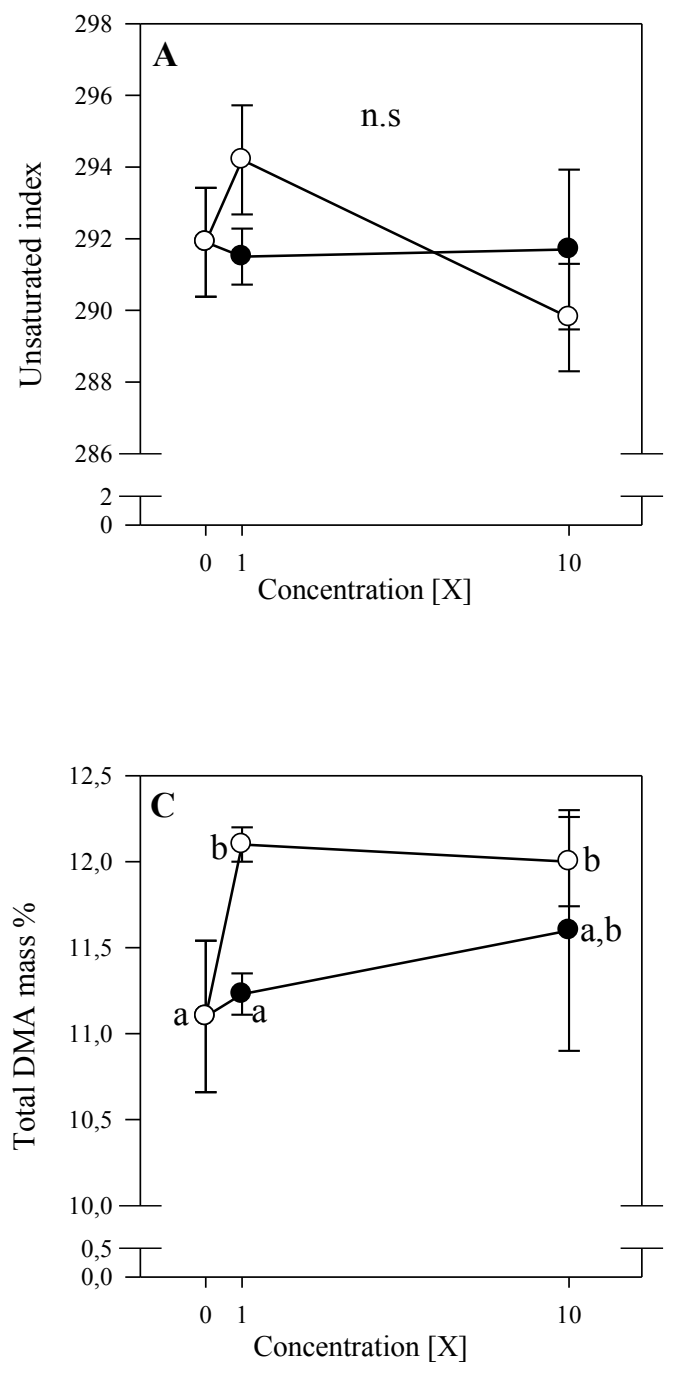
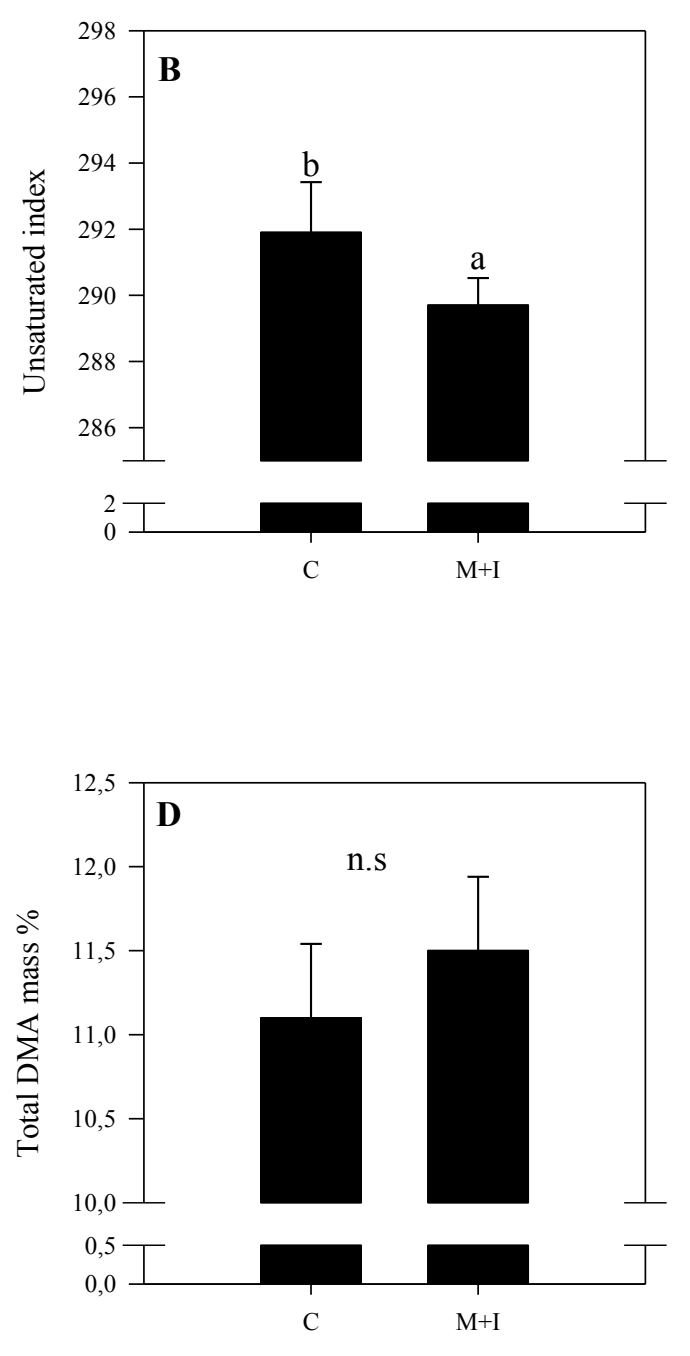